\title{
Güncel Sanatta Yeni Bir Yaklaşım Olarak "Melezlik"
}

Arş. Gör. Yunus Kaya

Makale Gelis Tarihi: 08.07.2016 Yayına Kabul Tarihi:01.04.2017

\section{Özet}

Son yıllarda, çeşitli gelişmelerle birlikte kültürlerin iç içe geçtiği ve disiplinlerin birbirlerine hızlıca yaklaştığı görülmektedir. Bu yakınlaşma sonucunda "şey-ler" "saf"lı̆ı̆ı ve tekilliğini kaybetmekte olup çoğulcu yapılar oluşturmaktadır. Bunun en önemli oyuncusu olan insan dokunduğu, ürettiği, olup çoğulcu yapılar oluşturmaktadır. Bunun en onemli oyuncusu olan insan dokunduğu, ürettiğı,
herhangi bir biçimde bağ kurduğu hemen tüm alanlarda, keskin sınırların zayıflayı, çerçevelerin ortadan kalktı̆̆ı tartışılmaz bir gerçektir. Küreselleşmeyi meydana getiren olguların birer aktivasyon görevi üstlendiği günümüzde, başta kültürel olmak üzere hemen her alanlarda bütünleşik ve çoğulcu yapıların meydana gelmesine neden olmuş ve bunun sonucunda da "melezlik" kavramını doğmasına neden olmuștur. Bu araștırma kapsamında, "melez-lik" kavramının terminolojik boyutu, günümüz sanatındaki rolü, varlık nedeni ve hareket alanı incelenecektir Özellikle de II. Dünya Savașından sonra, melez insan, melez kültür, melez ekonomi, melez dil gibi genişletilebilir söylemler haricinde, günümüzde, sanat alanında da "melez-lik" ifadesinin kullanılmasının normal, hatta gerekli olduğu örneklerle açıklanacaktır. Ayrıca, yapılan görsel analizler, eser okumaları ve literatür taraması yoluyla, sanatsal bir ifade tarzı olarak "Melez-lik", "Melez Sanat" ya da "Sanatta Melezlik" kapsamında değerlendirilen uygulama türlerinin "Güncel Sanat"ta konumlandırılması yapılacaktır.

Anahtar Kelimeler: Disiplinlerarasılık, Güncel Sanat, Hibrit, Melez, Melez Sanat.

\section{“HYBRIDITY” AS A NEW APPROACH IN CONTEMPORARY ART}

\section{Abstract}

In recent years, it has been seen that the cultures are intertwined with various developments and the disciplines are rapidly approaching each other. As a result of this rapprochement, "things" are losing their "pureness" and singularity and thus forming pluralistic structures. It is an indisputable fact that sharp borders are weakened and frames are destroyed in almost all areas wherever human beings, the most important player, are who touch, produce and connect in any way. In the present day the progress that bring globalization having each duty to activate, primarily between cultural, have caused almost in all fields to come to an integrated and pluralistic structure and as a result they has emerged the concept of "hybridity" for all. In this study, terminological dimension of the concept of "hybridity", its in the role of contemporary art and reason of its presence and in the framework of movement will be examined. Especially. After World War II discourses like human hybrid, hybrid cultures, hybrid economy, hybrid language and except of them, today in contemporary art, use of the term of "hybridity" being normal will be explained, even the term is as necessary. Through made visual work analysis and literature as a style of artistic expression within the scope of "hybridity", "hybrid art" or "hybridity in art" evaluation of the works type will be made and be determined the positioned of these terms in "Contemporary Art".

Keywords: Contemporary Art, Interdisciplinary, Hybrid, Hybrid Art. 


\section{Giriş}

Her canlı, soyunu devam ettirebilmek için çoğalmaya; yani üremeye ihtiyaç duyar. Çoğalmanın gerçekleşebilmesi için ise, çoğunlukla aynı türden ya da farklı iki türden, iki cinse ihtiyaç duyulur. Bu durumda aynı türe ait iki safkanın birleşiminden meydana gelen ürün, yine bir safkan olur. Bu araştırma kapsamında, hemen her konu ve alanda kullanılabilen "melezlik" kavramı incelenecek olup, bu kavramın sanatla olan ilişkisi sonucu doğan "melez sanat" ya da "sanatta melezlik" oluşumu değerlendirilecektir.

Stross'a (1999) göre, iki farklı türden ya da ırktan ebeveynlerin birleşimi sonucu doğan yavru, hem annedeki hem de babadaki belli özellikleri alarak heterojen bir yapıya sahip olacağı için "melez" olarak adlandırılabilir.

Türkdoğan'a (2014: 139) göre; melezlik, salt bir karışım ile açıklanamayacak kadar kozmik, mültipleks özelliklere sahip, mozaik ve zengin bir yapı meydana getirmesi durumudur.

İki farklı durumun karşılaşması, birbirleriyle kaynaşması, birbirini yok etmek yerine bir arada konumlanması, iç içe girmesi ya da üst üste gelmesiyle melezlik kavramının açıklanabileceği görülmektedir. Durumlardan biri diğerini nötrleştirmek, etkisini yok etmekyerine; benimsemek, kabullenmek birlikte yeni ve çok katmanlı yapı/lar oluşturmak melezlik kavramının güçlü yönünü vurgulamaktadır. Burada, birden fazla parçanın bir arada, kendine özgü özellikleriyle çoğulcu yeni bir yapı meydana getirmesi melez-lik kavramının kaçınılmaz bir özelliğidir

"Türk Dil Kurumu Güncel Türkçe Sözlük"e göre "melezlik" kavramı, botanik (biyoloji) ve hayvan-insan için kullanılmasının yanısıra, bir de mecaz anlamıyla kullanılmaktadır: bu kavram biyolojide; "değişik türden hayvan veya bitkiden üremiş (hayvan veya bitki), kırma, azma, hibrit, metis"; insan için; "değişik ırkta ana babadan doğmuş olan (kimse)" ve mecaz anlam olarak da; "katışık, karışık" şeklinde tanımlanır (Türk Dil Kurumu [TDK], 2016).

Hybridity-Hibrid-Melez terimi, biyoloji bilimi asıllı olsa da, 19. yüzyılda dilbilim ve ırksal teorinin kullanım alanına da girmiş ve böylece birçok disiplinde kullanılmaya başlamıştır. Sonraları göze çarpacak bir şekilde, popüler kültür çalışmalarında önemli bir değere sahip olmuştur (Tanrıbilir, 2010: 22).

Küreselleşme ile birlikte toplumsal ve kolektif kimlikler parçalanmış, kültürel sınırlar silinerek, yeni ve bütünleşik kültürel kodlar oluşturulmasıyla altkimlik, üst-kimlik ve melezleşme kavramları ortaya çıkmıştır (Kellner, 2001:
207).

Bireyler ya da gruplar tarafından diğer bireyler ya da gruplara bilgi, düşünce, tutum, gelenek ve duyguların aktarılması, toplumlararası ve kültürlerarası etkileşimi doğurmuştur. Bu etkileşim sonucunda farklı duygu, düşünce, tutum ve bilginin öğrenilmesi, öğrenilen bilginin de yaşama yansıtılması kaçınılmaz olmuştur. Öylece insanlar, çoklu kültüre sahip, toplumsal bir varlık olma özelliğini elde etmiştir. Böylesi bir birliktelik ve kültürel iç içe geçmişlik sonucunda kültürel melezleşme doğmuş olup her kültürün temelde çok kültürlü olduğu gerçeğini ortaya çıarmıştır (İşler, 2010).

Popüler kültürde kahvaltının bir ülkede, akşam yemeğinin bir başka ülkede yendiği; yazılı-görsel medyanın an içerisinde dünyanın hemen her tarafına ulaşabildiği, tüm bilgi ve faaliyetlerin siberuzayda tek tıklamanın ucunda olduğu, herkesin diğer herkesten haberdar olduğu postmodern dünyada saf kültürün olamayacağı; mevcut tüm kültürlerin "melez" olduğu söylenebilir. Zira Edward Said, tüm kültürlerin birbirlerinin içine karıştığını, hiçbir kültürün katışıksız olmadığını söylerken, tüm kültürlerin melez özelliğine vurgu yapmaktadır (Said, 2004: 31).

Günümüzde dil, teknoloji, sanat, siyaset, ticaret ve bilginin hızlı yayıldığı kadar, kültürler arası geçiş de bir o kadar hızı akışmaktadır. Bu akıştan en çok içerisinde etkilenen birey başka kültürleri tanıma, benimseme ve uyum sağlama sürecinde kültürel bir harmoni meydana getirmekle bbirlikte, aynı anda birçok yerde ve birçok kimlikte varlık alanı oluşturabilmektedir. Kültürel kaynaşmanın yanı sıra saflığın keskin sınırlar zayıflar ve bireyler sürekli yeni kültürlerle tanışma ve yeni kimlikler kazanma olanağını elde eder. Böylelikle mevcut karakterine yeni karakterler eklenen birey ya da bireyler, çokçuluk ilkesine uygun ve çok kültürlü melez toplumların sınırlarını genişletmesine yol açar (Türkdoğan, 2014: 140).

Birçok alanda olduğu gibi melez kültür ve melez sanat oluşumunda teknolojinin gücü ve etkisi yadsınamayacak kadar çoktur. Bu bağlamda, sanat, bilim ve endüstri üzerine yapılan sistematik değerlendirme anlamında kullanılan teknoloji, tüm bu alanları hem kolaylaștırmakta hem de yetkilerini devralmaktadır. Özünde teknoloji, kendi başına kültürel belirleyici olmasa da belirli bir kültürün üretimi olup bilim ve sanatın aynı tabanında buluşmasına yardımcı olur (Candemir, 2006).

Insanın olduğu her yerde ve insanı ilgilendiren her tür faaliyette; sanatta, eğitimde, edebiyatta, bilimde, ekonomide ve teknolojide kültürlerin böylesi hızlı bir biçimde kaynaşıyor olması sonucunda küresel bir görsel kültür yapılaşmasına katkı sağlamaktadır. Bu bağlamda, Leppert'ın görsel 
kültürü hem televizyon, sinema, müzik klipleri, bilgisayar teknolojisi, alışveriş merkezleri, reklamlar, dergiler ve gazetelerin yarattığı imgeleri içine alırken, hem de resim, çizim, heykel, mimari, film ve buna benzer şeyleri kapsar (Uysal, 2011).

Melez sanatın oluşumunda bilim, teknoloji, savaşlar vs. sonucu göçler gibi farklı birçok dinamikle birlikte disiplinlerarası araştırmaların da önemli etkisi vardır. Disiplinlerarası sanatın ilk belirtileri, 20. yüzyılın başlarında ortaya çıkan, kübizmin deneysel uygulamalarından doğan ve sanatta nesne anlayışına dönüşüm kazandıran kolaj yapıtlarında olduğunu savunan Yılmaz'a göre sanattaki bu yeni tutum; "akademik ve akademik olmayan düşünce alanlarını bir araya getirerek sanat yapmanın yolunu açmıştır" (2015: 997). Daha özgür anlatımlar sunduğu düşünülen kolaj tekniği, hazır-nesne, ses, bilgisayar, internet, TV ve siberuzay gibi çağdaş sanat malzemeleri, sanatçının konu ya da materyal seçiminde alternatif disiplinlerden yararlanmasına olanak sağlamaktadır. Bu, disiplinlerarası yakınlaşmanın sonucunda en az iki disiplinden yararlanılarak elde edilen ürün çok sesli, çok yönlü, kitlesel ve deneysel yapıya sahip; saflıktan uzak değerler yumağı özeliğini taşır.

Günümüzde disiplinlerarası anlayışta sanatçının yapııını oluştururken ne tür bir malzeme kullandığı ya da onu nası kullandığından çok, eserin kavramsal boyutu, ne anlattığı, nasıl anlattığı, hissettirdiği önem kazanmaktadır. Sadece el iş̧iliğini konuşturan zanaatçı kimliğini; tasarlayan, düşünen ve düşündüren yaklaşım, yerini tasarladığını en uygun hangi malzemeyle dile getirebileceğini sorgulayan bir sanatçı kimliğine bırakır. Günümüz sanatına bakıldığında video sanatı, dijital sanat, şehir sanatı ve birçoğu isimlerinde disiplinlerarası bilgiyi barındırmaktadır (Kara, 2003).

Çağdaş Sanatta malzemenin ve üretim sürecinin başka disiplinler ile birlikte harmanlanıp aynı potada eritildiğini ve izleyiciye sunulduğunu belirten Kahraman, bu etkileşimin sanat için meydana getirdiği sonucu şu iki cümle ile anlatır; "İster plastik ister görselsanat dallarından biri olsun, disiplinlerin iç içe geçerek birbirleriyle etkileşim halinde oldukları görülmektedir. Disiplinlerarası kurulan bu etkileşim, sanatın sınırlarını belirsizleştirmektedir" (Kahraman, 2015: 365).

Arapoğlu, disiplinlerarasılığın ortaya çıkışı ve devamında etkilediği sanat alanlarını şu cümlelerle özetler:

19.yüzyılda sanatlar arasında bütünlüğü ve kaynaşmayı hedefleyen, Richard Wagner tarafından ortaya konulan "gesamtkuntwerk" (total art; bütüncül sanat) kavramı ile disipliner sanat yaklaşımı sorgulanmaya başlamıştı. Bu sorgulamanın etkileri 20. yüzyılda ortaya çıkmaya başlamıs, Fütürizm, Dadaizm, Sürrealizm gibi avangard sanat akımlarının - bunlara kısmen Kübizm ve Alman Ekspresyonizm eklenmelidir - Marcel Duchamp ve John Cage gibi sanatçıların işlerinde, farklı üretim biçimlerinin bir araya getirilip, kullanımında görülmüştür. Öte yandan, 20. yüzyılın ikinci yarısında özellikle 1960'ların Fluxus, Oluşumlar (Happenings) ve Performans Sanatı gibi sanat akımları ve sanat üretim yöntemleri, disiplinleraras (interdisciplinary) bir üretim biçimini benimseyerek ve sanat kapsamı içerisindeki alanları ve sanat ile hayatın diğer olguları arasındaki sınırları sorgulayarak, bu sınırları belirsizleştirmeye çalışmışlardır (Arapoğlu, 2013: s.y).

20. Yüzyıl sanatta, geleneksel estetik anlayışı ve alışılagelmiş görme biçimlerinin yerle bir edildiği bir dönemdir. Bu değişimin hiç şüphesiz ki en önemli figürlerinden biri Fransız sanatçı Duchamp'dır. Duchamp'ın readymade'leriyle birlikte, sanatçıların geleneksel ve sınırlayıcı belli malzemeye olan zorunlu ihtiyacının ortadan kalkması anlamına geliyordu. Böylelikle, sanata yüklenen anlam yeniden sorgulanmaya başladı. Müze ve galeri gibi alanlarda sergilenen sanat yapıtları bu mekânların dışına çıkarak doğanın bir sanatsal faaliyet ve sergileme alanına dönüştü. Kitle iletişim araçlarında yaşanan son gelişmelerle birlikte siberuzay / internet üzerinden sergileme ve satış alanları oluşturularak sanatçının bir kuruma bağlı olma zorunluluğu da ortadan kalkmasına katkı sağladı. Ayrıca seyirci katııımlı sanatsal faaliyetler / sanatsal pratikler interaktif ve kitlesel katılımlar gerçekleştirmesiyle sanat ile hayat aynı potada buluşma noktasına geldi. Son 50-60 yılda sanatta yaşanan tüm bu gelişmeler, birbirine bağlı birçok faktörle birlikte, ancak disiplinlerarasındaki sınırların yok olmasıyla ortaya çıkan melez sanat anlayışı ile açıklanabilir.

1960'larda merkez üssü Amerika olan pop, op, minimal, kavramsal, çevresel, yoksul, fluxus ve oluşum gibi adlar altında modernizmi başkalaştıran; figür, nesne, temsil ve konu gibi modernizmde kapı dışarı edilen değerler yeniden içeri alındı. Böylelikle, estetiğin terki anlamına da gelen bu değişim, hem "yaşam ve "sanat" arasındaki sınırları hem de "yüksek sanat" ve "alçak sanat" arasındaki sınırları alabildiğince zayıflatıp muğlaklaştırdı (Yılmaz, 2013: 264). Böylelikle sanatçı, ulaşılmaz olmaktan çıkıp topluma karışı. Artık doktor, öğretmen, mühendis, mimar, esnaf; kısaca herkes sanatçı olabilir fikri toplum içerisinde hızlıca yayılmaya başladı.

Postmodern olarak anılan sanat pratiklerinden Dada hareketi, sanata karşı bir manifesto ile ortaya çıkmıs. Marcel Duchamp'ın hazır-yapım sunumlarıyla, "sanatın ne olduğu?" sorusuna yanıt aranmışır. Öte yandan sanatsal faaliyetlere, yazı gibi pek çok farklı malzemenin kullanımı, sanatın temsil biçiminde disiplinlerarası bir özgürleşmeyi de beraberinde getirdi. 
Kavramsal sanat pratiklerine kapı aralayan bu oluşum, imaj, kavram, yazı ve hazır nesnelerin birlikte kullanılmasıyla, temsilin düşünsel ve kavramsal dönüşümüne yeni biçim arayışları eklenmiştir (Alp, 2013).

Dada Kübizm, Konstrüktivizm ve Fütürizm gibi dönemin avangard sanat hareketlerini aynı gövdede toplamasıyla, disiplinlerarası sanatın çok boyutlu görsel dilini meydana getirmiş. Pop sanat, kitle iletişim araçlarının yaygınlaşmasıyla, büyük kitlelere doğrudan hitap etme olanağı elde etmiş. Kavramsal Sanat, her gün karşılaştığımız nesnelere en uygun gelen şeyleri bir araya getirerek, yeni bir gerçeklik ortaya koymuştur.

"Performans sanatı tiyatro, müzik, dans, şiir, video ve sirk gibi farklı disiplinlerin öğelerinden yararlanabilir. Performans Sanatının bu disiplinlerarası yaklaşımı, yeni sanat anlayışları ile çeşitli malzeme ve teknik anlatım olanaklarından faydalanmasını da olanak sağlar" (Nalbantoğlu, 2012).

Müzeler ve galeriler sanat ile toplum arasında yalıtım oluşturduğunu savunan happening -oluşumcu sanatın temsilcilerinden Allen Kaprow, izleyici ve sanatçı arasındaki sınırı kaldırmak için alternatif mekân ve yöntem arayışlarına girmiş. Kaprow, etkileşim ortamı sağlayan oluşumlarında, olağan gösteri biçimlerinden ve özgür anlatım yöntemlerinden yararlanmış. Her ikisinde de farklı disiplinlerin bir arada kullanıldığı performans sanatı ve oluşum sanatı melez sanat örneklerindendir (Atakan, 1998: 67-70).

Postmodern sanatın temel özelliklerinden çoğulculuk ya da disiplinlerarsı yaklaşım; günümüz sanatında önemi artan, multipleks bir yapı olarak karşımıza çıkmaktadır. Multidisipliner yaklaşım kullandığı materyaller veya hazır tüketim nesneleri haricinde, Postmodern sanatın pastiş özelliğinden de yararlanarak hareket alanını genişletir ve farklı sanat disiplinlerinin bir araya getirilmesine olanak sağlamaktadır. Nam June Paik veya Joseph Beuys gibi birçok sanatçı, çalışmalarında farklı kültürel özellikleri ve imgelemler ikonografik olarak kullandığı eserlerinde gözlemlenebilir (Şahin, 2015).

Teknolojideki gelişmeler, disiplinleri birleştirmede sağlıklı deneylerin yapılabilmesinde sinema, video, resim, heykel, müzik ve tasarım alanlarındaki yakınlaşmayı hızlandırmış, farklı melezleme kullanımı ve çeşitli eşleştirmelere olanak sağlamıştır. Bilgisayar, televizyon, kamera, telefon vb. teknolojik materyaller ile geleneksel malzemeler arasında çeşitli ifade biçimlerini güçlendiren bir tür entegrasyonu ortaya koyan N. J. Paik'in farkı yıllarda farklı versiyonlarını oluşturduğu Buda'nın teknoloji ilişkisi melez sanat olarak alıntılanabilecek önemli örneklerden biridir. 1994'te yapılan Techno Buddha (Görsel 1), video ve elektronik ortamı içeren iş, çeşitli materyallerin kullanımı ve bunların ilişkilendirme biçimi yanında, işin kavramsal boyutu, çok yönlü oluşuyla, tam anlamıyla melez bir yapı olma özelliğine sahiptir.

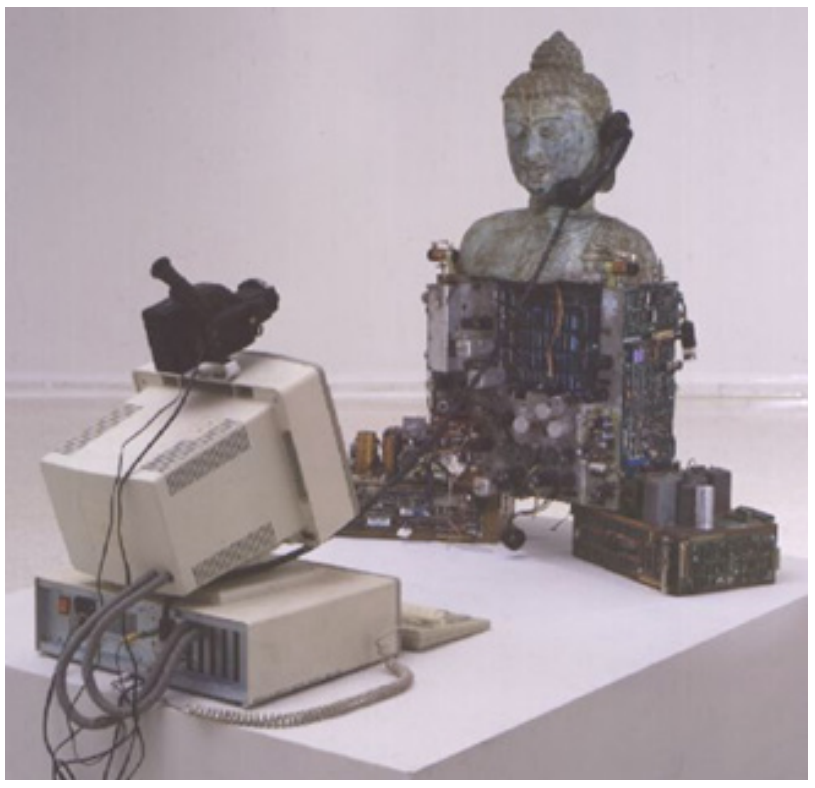

Görsel I. Nam June Paik, Techno Buddha, 1994, buda kafası, şasi, bilgisayar monitörü, klavye, telefon, yaklaşık $110 \times 105 \times 40 \mathrm{~cm}$

Insan bilincini manipüle etmekte çok başarılı bir araç olarak kullanılan televizyonu June Paik onu bir sanat malzemesi olarak seçmiş ve monitörlerin işlevlerini değiştirerek sisteme karşı birer eleştiri ifadesi haline getirmiştir (Beyaz, 2016).

Paik'in yaptığı videolu işlerinden sadece biri olan bu çalışmasında, bilgisayar ekranı üzerine konumlandırılmış video kayıt cihazı karşısında, kulağında bilgisayar bağlantılı bir telefonla duran Buda görüntülü konuşma yapar durumda ifade edilmiştir. Burada Paik'in söylediğinden çok daha fazlasını, ortaya koyduğu is anlatmaktadır. Buda'nın ekranda ne gördüğü imkânsız olsa da Buda ve ekran birbirleri ile iletişim içerisindedir. Burada eski ile yeninin bir karşılaştırması ortaya konulmuştur. Buda eski dünyanın, bilgisayar ise yenidünyanın bilgeleri olarak temsil görevi üstlenmiştir (Grabarz, 2010).

\section{Arapoğlu'na göre;}

Disiplinlerarasılık, belirli bir biçimde "gerçek dünyanın" sistem sorunlarına işaret etmeye odaklanmakta ve konu edinilen sorun ile ilgili olarak çok çeşitli disiplinlerden 
katıımcıları yeni bir bilgi yaratmak için sınırları așmaya zorlamaktadır. Özsel olarak disiplinlerarasıı̆ğın, en önemli nitelikleri bütünleşme ve işbirliği derecesidir Disiplinlerarası projeler, disipliner bakış açılarını birbirine bağlamayı amaçlamakta ve potansiyel olarak komşu bir disiplinin perspektifinden hareketle var olan kümülatif bilginin denenmesine olanak sağlamaktadır (Arapoğlu, 2013: s.y).

Disiplinlerarasılık sonucu oluşturulan bir çalışma, nesnel bir biçim şeklinde ortaya konmasa da metin, biçimin yerine geçebilir ve ses hileleri, dijital miksaj ve baskı teknikleriyle birlikte fantastik bir boyut kazanabilir. Çağdaş sanat akımları içinde disiplinlerarasılık farklı disiplinleri bir araya getirmekle kalmamış, aynı zamanda teknolojik yeniliklere bağı sanat yapma olanağını da sağlamıştır (Yılmaz, 2015: 997).

1969'da Gilbert ve George'un "Şarkı Söyleyen Heykel" adındaki uygulamalarında, takım elbiseler içinde kendilerini büsbütün altın renge boyayıp bir masanın üstünde dans etmişlerdi. Bu performans ayrıca müzik ile desteklenmiştir. Gilbert ve George bununla gündelik etkinliklerinin hepsinin birer heykel ile anlatılabileceğini belirtirler. Bu uygulamalarıyla sanatçılar, farklı disiplinlerin bir arada olduğunu göstermişlerdir (Smith, 1996: 274-275). Gilbert ve George'un bu performanslarını sadece heykelle, resimle, müzik ya da tiyatroyla/dansla anlatılamayacağının açık göstergesidir. Burada bu disiplinlerin her birinden bir parça alınıp zengin bir birleşim oluşturulmuştur.

Kavramsal sanatla uğraşan sanatçı Claude Closky'nin web sayfasındaki bağlantılara bakıldığında izleyici, çağdaş sanatın ünlü isimlerinden oluşan ".com" uzantılı internet siteleri ile karşışıır ve bu liste Adams, Akerman, Alys, Amer, Araki ile başlar. Listede yer alan tüm bağlantılar belli şirket sitelerine yönlendirir, örneğin, www.billingham.com'a tıklandığında elektronik eşya aksesuarları satan bir sitede karşınıza çıkar. Sanatçıların isimlerini paylaşan ürün ve hizmet yelpazesi küçük, tuhaf bir veri tabanı oluşturur ve bu arama işlemi kişiyi sanatçı ismini markalar olarak düşünmeye, ikna etmeye sürükler ve sanatçı işlerini de ".com" mantığı çerçevesinde algılamaya teşvik eder. Bu örnekte olduğu gibi metalar kültürel karakter kazandıkça, sanat daha çok metalaşır ve kapitalizmin buyruğuna girer ve diğer her tür nesne gibi sanat da tüketim kültürünün metası haline gelir (Stallabrass, 2010: 76-77), şrketlerin sanat üzerindeki etkisi bağlamında verilebilir önemli bir örnek olduğu düşünülmektedir. Bu metalaşma sonucu meydana getirilen sanatta, üretim, pazarlama / tanıtım ve tüketime yönelik internet, bilgisayar, reklam, tasarım gibi etkilerle, misyonu farklı olsa da, ortaya çıkan sanat melez bir yapıya sahiptir.

Günümüzde sanatçılar, güncel teknolojiyle birlikte, biçimsel ve düşünsel açıdan farklı disiplinlerle interaktif bir ilişki güderek, çeşitli alanla ilgili arayışlar ve araştırmalar içine girmişlerdir (Özel, 2007: 16). Bu anlamda, disiplinlerin birilileriyle kurdukları bu ilişkisellik bağının ucu açıktır ve sınırları yoktur.

Kitle kültürü öğelerini, rasgele kesip oyun oynar gibi yeniden birleştiren montajlama ve tesadüfen kullanım nesneleri bulan sanat, tüketim ekonomisinin rüyası olarak düşünülebilir. 1960'lar Amerika'sında sanat dünyası, dikey olarak çok katmanlı, yatay olarak heterojen bir nitelik taşıyan ve bir birini kesen pek çok ortaklığı ve iş ilişkisini kapsayan karışık, çok yapılı özelliğe kavuşmuştur (Stallabrass, 2013: 31-74).

Reklam panolarından yola çıkarak farklı bir ifade biçimi geliştiren günümüz önemli sanatçılarından Amerikalı Jenny Holzer, metne dayalı Dil, Kurulum ve Kamusal Sanat'ı bütünleștiren melez işleri ile tanınan kavramsal bi sanatçıdır. Holzer, kamuya açık alanlarda mimari ve reklamcılık üzerine fikirler sunan kelimeleri projeksiyon ve led ışıları kullanarak yansıtır. Çalışmaları genellikle izleyiciye mesajlar veren çok güçlü bir ifadeye sahiptir. Çalışmalarııı projelendirir, bastııı ve sergiler; reklam panoları, tezgahlar, tisörtler, duvarlar ve kent mimarisini metinlerini sunmak için kullanır. Holzer mesajlarında seyirciye postmodern tecrübesini yansıtan rahatsız edici sorunları, siyasi görüşleri ve kişisel mesajları içeren metinler sunar ve asıl iş, sunulan mesaj olarak değerlendirilebilir. Holzers'ın çalışmasının gücü, sunum, metin, sembolizm ve malzemeler gibi birçok unsur anlam oluşturmak için bir araya geldiğinde gerçekleşir (Web: Jenny Holzer, 15.02.2017)

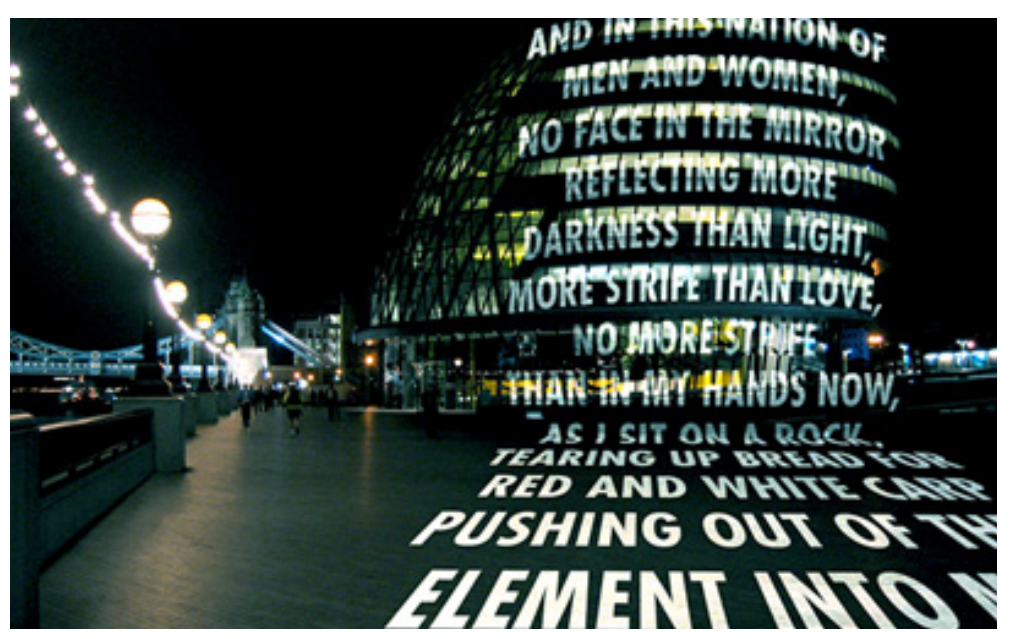

Görsel 2. Jenny Holzer, For London, Projections at various sites, 2006, London 
Esther Stocker, kullandığı siyah bant, fotoblok ve basit ahşap malzemelerle mekânlara sıra dışı görünümler kazandırmakta. Onun yerleştirmelerdeki iki boyutlu nesneler, tasarım, psikoloji ve teknoloji sayesinde üçüncü boyut kazanarak, izleyiciye basit ve soyut geometrik çalışmalarla, görsel algı oyunları sunmakta. Çoğunlukla siyah, beyaz ve grilerden oluşan bu enstalasyonlar seyirciyi belirsizliğe sokan bir tür algı oyunları yoluyla iki boyutlu yüzeylerin üçüncü boyutta yeniden sorgulanmasına neden olmaktadır (Taşçıŏlu, 2013: 115, 149).

Hollanda'lı sanatçı Martijn Sandberg'in 2008 yılında "I Will Survive" (Hayatta Kalacağım) isimli çalışması (Görsel 3), yere özel olma özelliğiyle dikkat çeken bir örnektir. Hollanda Hardenberg'de şehrin içinde kalmış eski mezarlığın bir kenarında 25 metre uzunlukta, 3 metre yükseklikte yerleştirilen çitler üzerinde "I Will Survive" cümlesiyle sanatçı, görünürde çiti andırsa da bunun mezarlığın etrafını saran çit olmadığını ve bunun bir sanat yapıtı olarak tanımlanması gerektiğini belirtir. Bu çitler üzerindeki yazı sadece belirli açılardan net bir şekilde okunabilmektedir. "Sanatçı izleyicinin bakış noktasına göre algılanabilen bu çalışmasıyla; bitişikteki mezarlığın dehşet verici olacağı düşüncesinin aksine, yaşam ve ölüm, eylem ve hareketsizlik arasındaki karşıtlığı belirtir. Burada yaşam ve ölüm arasında birlikte sunulan karşıtıı, izleyenin algısını değiştirmektedir" (Saygı, 2016: 97).

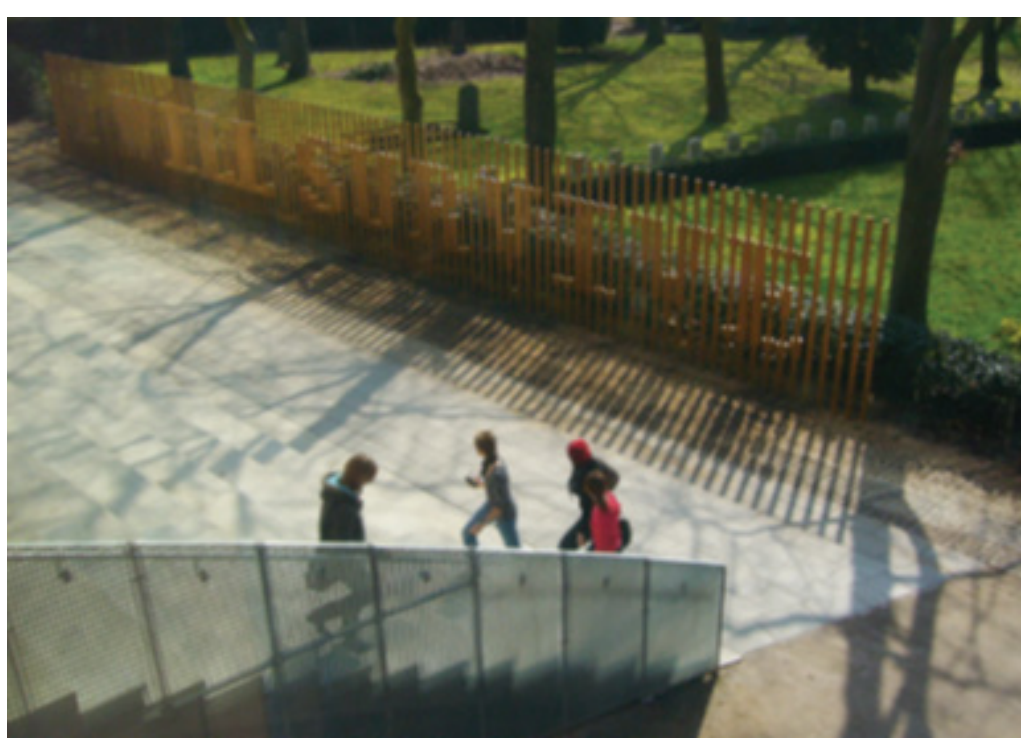

Görsel 3. Martijn Sanderg, "I Will Survive” (Hayatta Kalacağım), 2008, Hardenberg, Hollanda
Bu tür multidisipliner bir anlayışla yapılan ve alıcıya sunulan yerleştirme sanatı, çağdaş sanatta mimarlık ve performans gibi, diğer birçok görsel sanat disiplininden destek alan melez (hibrid) bir sanat üslubudur. Uygulama esnasında, eserin sergileme veya gösterim aşamalarını vurgulayan yerleştirme, önceleri, galeri ve müzeler tarafından radikal bir sanat yaratım biçimi olduğu düşünülse de, 1970-80'lerde açıkça tanımlanan bir tür olarak kabul edilmiş ve 20. yüzyıl sonlarında baskın bir sanat türü olmayı başarmış ve güçlenerek günümüze kadar gelmiştir. Günümüz yerleştirmelerinde, günlük ve doğal malzemeler haricinde, video, ses, performans, Internet gibi yeni disiplinlerden de yararlanılmaktadır (Kurt, 2013).

J. Walter Thompson'ın, Red Cross için ülke dâhilinde 2500' den fazla nüfusu olan her şehir için yaptığı araştırma sonuçlarına göre, bir "iletişim sanatı" olarak tanımlanan reklamcılık Algür'e göre (aktaran Alıcı, 2014), bünyesinde çok sayıda melez örnekler barındırmaktadır.

Farklı kültürlerden içeriğin bir arada olduğu reklam stratejilerinde, birden fazla kültüre ait simgesel, görsel ya da dilsel / fonetik ileti ve mesajlar bulunmaktadır. Bu tür reklamların içeriği sadece reklamın bağlı olduğu kurum ya da yayınlandığı ülke tarafından belirlenmez, aynı zamanda reklamın basımı veya yayınlanmasında ne tür iletişim araçları kullanıldığı da önemlidir. Örneğin bir Fransız markası, Japonya'da yayınladığı ya da yayımladığı bir reklamda bir Amerikalı yıldızın rol alması bile "melez reklam"a örnek olarak gösterilebilir. Bu görsel (Görsel 4) 1960'lı yıllarda yayınlanan bir dergi reklamı olup İngiltere'de yaşayan Türklerin ve diğer Doğuluların ilgisini çekmek, onları ikna etmek için bir şekerleme satış reklamı için tasarlanmıştır. Reklamda "Doğu'dan gelen muhteşem tat" sloganıyla, "Turkish Delight" adı verilen ürün, bir İngiliz markasıdır. Reklamda, Doğu masal kültüründen alınan uçan bir halıyla eğlenceli görünen bir yolculuğa çıan Avrupalı kadın, FRY's Turkish Delight yemektedir. Reklamda kullanılan dil İngilizce, ürün Türk şekerlemesi, ancak İngiliz markası bir ürün, görseller ise Doğu ve Batının melez bir bütünlemesi olduğu görülmektedir (Tanrıbilir, 2010: 178-233).

Tiyatro ve opera gibi yapımlarda sahne tasarımları yapan Es Devlin, 2013'te Lucy Kirkwood'un yazdığı Chimerica oyununun Londra Almeida sahnesindeki gösterimini tasarlarken fotoğraf çekme ve kamera kaydı olanakları üzerine yoğunlaşarak bu mekanik etmenleri gösterinin bir parçası haline getirmiştir. Gösterinin bu sahnesi (Görsel 5), içerisinde üç oda barındıran yarı saydam basit bir küp olarak tasarlamış böylece küp, her bir odanın görülebilmesi için döndürülebilir hale getirilmis olup, bu tasarımla senaryo, her provada farklı sahne gösterimleri izleyiciye sunulmuştur 
(Williams, 2015).

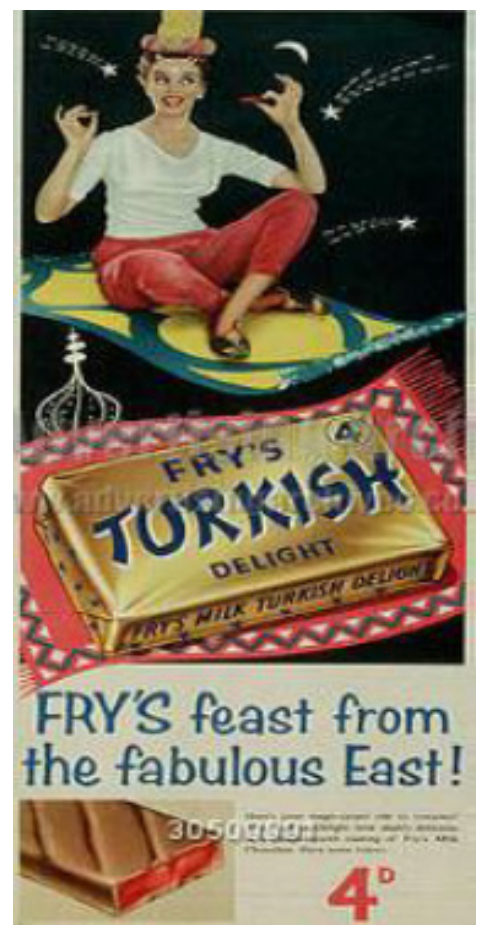

Görsel 4. FRY’S Turkish Delight, Melez Kültürel Reklam Iletisi



Görsel 5. Es Devlin, 2013, “Chimerica” Sahne Tasarımı, AlmeidaTheatre, Londra.
Çoğulcu anlayışın öne çıktığı günümüz sanatında, özellikle güzel sanatlarda sanatçılar, bir tek kimlik taşımasından ziyade sentezci bir anlayışla, katılımcı bir performansa dönüşen aynı zamanda, farklı kültür ve teknik bireşimlerini oluşturan sanat eserleri ile karşımıza çıkmaktadır. Eklektik bir yapı içerisinde sunulan Hedi Xandt 'in Koruluk Tanrıçası adlı eserde sanatçı, kendi kültürü dışında farklı bir kültür ve eseri kullanmış; dünya sanatı tarihi içerisinde başyapıt niteliği taşıyan eserleri, özgün sanat nesnesine dönüştürerek melez / sentez bir eser ürettiği gözlemlenmiştir (Şahin, 2015).

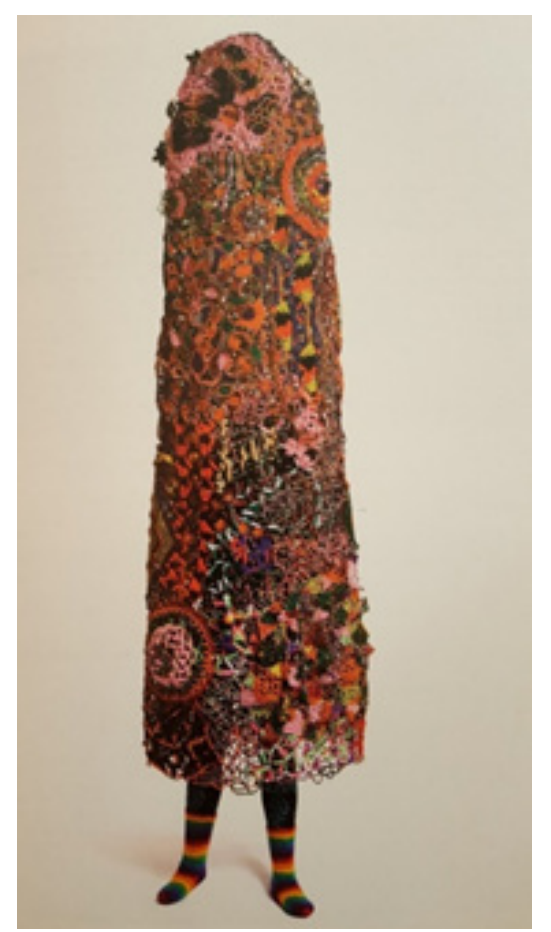

Görsel 6. Nick Cave, Sesgiysi (isimsiz), 274,3 × 91,4 x73,7,

sentetik saç (peruk), yün, metal teçhizat, 2009

Amerikalı sanatçı Nick Cave'in melez olarak nitelendirilebilecek uygulamaları "sesgiysileri / soundsuits" sıradışı örnekler arasında gösterilebilir (Görsel 6). Özünde statik sergileme düşüncesiyle tamamı süslenmiş giysilerden meydana gelen sanatçının işleri zaman zaman farklı hareket alanları ile bütünleştirilir. Cave, işlerini bazen fotoğraf ve video filmleriyle belgelerken bazen de dans gibi performanslarla bağlantılı hale getirerek kayıt altına alınır (Wilson, 2015: 90). 


\section{Sonuç}

Güncel sanat pratiklerini anlayabilmek için tek bir duyuya bağlı kalmak, tek bir disiplinle yaklaşmak ya da konvansiyonel metotlarla onu çözümlemeye çalışmak mümkün olmadığı için, bu tür yöntemler kişiyi daima yanlış sonuçlara götürecektir. Zira güncel sanat anlayışında, birden çok disiplinin işbirliği veya alt yapı desteği sonucu oluşturulan çok katmanlı işler üretilmektedir. Bunun yanı sıra tiyatro, mimari, resim, heykel, kaligrafi ve gösteri gibi alanlar da iç içe geçerek kavrama dayalı çeşitli sonuçlara gidilmektedir. Bu katmanların her biri, farklı kültürlere ve farklı özelliklere sahip olması bakımından, bu tür uygulamaların hakkıyla anlaşılabilmesi için de, birden fazla duyuya intiyaç olduğu gibi ayrıca, duygu bağına da gereksinim duyulabilir.

Üretiminde, sunulmasında ya da okunmasında en az iki disiplinin bir araya getirilmesi ile oluşturulan, bir tek sanat disipliniyle tanımlanamayan, yapısında bulundurduğu birden fazla dinamikle zengin ve kompleks bir özelliğe sahip olan sanat uygulamaları, bu gibi bütünleşik yapısından dolayı, melez olarak adlandırılır. Sanatsal faaliyetlerde disiplinlerarası kaynaşma sonucu sanattaki kullanımıyla bu yaklaşım türü, her şeyden önce güncel bir sanat üslubu ve bir kültür olarak değerlendirilmelidir.

1950-60'lardan sonra ortaya çıkan hemen tüm sanat üslupları veya eğilimler için melez kavramının kullanılması mümkündür. Video Sanatı, Internet Sanatı ve Dijital Sanat, Yerleştirme, Fluksus, Performans, Süreç Sanatı, Çevre Sanatı sanatçıları ve günümüzdeki hemen her bir sanatçının ortaya koyduğu ürün, iş, pratik, yapıt ya da etkinlik, eklektik ve kozmos; heterojen yapılara sahip oldukları için sanatta melez yakılışımlar kapsamında değerlendirilmelidir. Atıkmalzemeler, buluntu nesneler, karalamalarve yazııı ifadeler yanında; fotoğraf, film, video, internet gibi teknolojik gereçler, izleyici, hatta mekânın kendisi doğrudan melez sanat oluşumlarının birer parçası olarak kullanılabilmekte ya da bu tür sanat pratiklerinin doğrudan içerisinde yer alabilmektedir.

Güncel sanat pratiklerinde sonuçtan çok, sürecin ön planda olduğu gerçeğinden yola çıkarak, birbirine yakın ya da uzak olduklarına bakılmaksızın birden fazla disiplinin işbirliği ve altyapısı ile oluşturulan melez sanat pratiklerinin sadece geleneksel resim, müzik, heykel anlayışıla okunmaya çalışılması kişiyi kusurlu bir değerlendirmeye götürecektir. Bu tür uygulama biçimlerinin çok kültürlü (birden çok disiplin kültürüyle) bir yaklaşımla analiz edilmesi ve onları anlama yoluna gidilmesi, yapıtın doğru anlaşılabilmesi için önemli; hatta bir gereklilik olarak görülmektedir. 


\section{Kaynakça}

Alıcı, B. (2014). Reklam Bir Sanat mıdır?. Celal Bayar Üniversitesi Sosyal Bilimler Dergisi, 12 (I), 90-II7.

Alp, K. Ö. (20I3). Sanatın Temsili ve Postmodern Sanatta Temsil. Süleyman Demirel Üniversitesi Güzel Sanatlar Fakültesi Hakemli Dergisi, Art-E, 6 (I2), 40-6I.

Arapoğlu, F. (20I3). Sanatta Disiplinlerarasılık ya da Disiplinlerarası Sanat. Akbank Sanat. http://www.akbanksanat.com/detay/2 I-I I-20I3/sanatta-disiplinlerarasilik.

Atakan, N. (1998). Arayışlar: Resim ve Heykelde Alternatif Akımlar (çev. Z. Rona). istanbul: Yapı Kredi Yayınları.

Beyaz, G. G. (2016). Nam June Paik ve Onun Tabula Rasa'sı: Video. İstanbul Aydın Üniversitesi Dergisi, 8 (29), I-I6.

Candemir, T. (2006, Nisan). Çağdaş Teknolojinin Sanat Dallarına Etkileri ve Yardımcı Yazılımlarla Bilgisayarda Resim Yapmak. 6 th International Educational Technology Conference'inda sunulmuş bildiri, Department of Educational Sciences Eastern Mediterranean University Famagusta, Kuzey Kıbrıs.

Grabarz, W. (2010). http://enchanteddonkey.blogspot.com.tr/2010/03/nam-june-paik. html (I8.I.2017) sayfasından erişilmiştir.

İşler, E. (20I0). Mitler ve Kültürlerarası Illetişim. Pamukkale Üniversitesi Sosyal Bilimler Enstitüsü Dergisi, (5), 17-22.

Kahraman, D. (2015). Türkiye'de Edebiyat-Seramik Çerçevesi İçerisinde Disiplinleraras Bir Etkileşim:" Gölgesizler" Seramik Sergisi. Journal Of International Social Research, 8 (39), 364-375.

Kara, D. (2003). Sanat Eğitiminde Disiplinler Arası Sanat. Yapı Mimarlık ve Kültür Sanat, (260), 108-109.

Kellner, D. (200I). Popüler Kültür ve Postmodern Kimliklerin Inşası (çev. G. Seçkin). Istanbul: Doğu Batı Yayınları.

Kurt, E. K. (20/3, Mayıs-Haziran). Güncel Sanatin içinde Bir Melez Ifade Alani: Yerleştirme (Enstalâsyon). Warhola, (4), İstanbul. (https://issuu.com/alanistanbul/docs/ www.alanistanbul.com.com) sayfasından erişilmiştir.

Melez. (20/6). Türk Dil Kurumu içinde http://www.tdk.gov.tr/index.php?option=com gts\&arama $=$ gts\&guid = TDK.GTS.5734a4030ff677.22600349 sayfasından erişilmiştir.
Nalbantoğlu, F. (20I2). Performans Sanatı, Teknoloji Ille İlișkisi ve Sahne Sanatları Eğitimindeki Rolü. Süleyman Demirel Üniversitesi Arte-Güzel Sanatlar Fakültesi Sanat Dergisi, 5 (10), 199-207.

Özel, V. (2007). Plastik Sanatlarda Disiplinlerarası Etkileşimler ve Seramik Sanatına Yansıması. Yüksek Lisans Tezi, Anadolu Üniversitesi Sosyal Bilimler Enstitüsü. Eskişehir.

Said, E. W. (2004). Kültür ve Emperyalizm: Kapsamlı Bir Düsünsel ve Siyasal Sorgulama Çatısması (çev. N. Alpay). İstanbul: Hil Yayın.

Saygı, S. (20I6). Kamusal Alanda Sözcüklerle Sanat. Atatürk Üniversitesi Sanat Dergisi, (29), 87-99.

Smith, E. L. (1996). 20. Yüzyılda Görsel Sanatlar (çev. E. Kılıç, B. Kovulmaz ve O. Akınhay). Istanbul: Akbank Kültür Sanat Yayınları.

Stallabrass, J. (2010). Sanat A.Ş. Çağdaş Sanat ve Bienaller (çev. E. Soğancılar). İstanbul: Iletişim Yayınları.

Stross, B. (1999). The Hybrid Metaphor: From Biology to Culture. The Journal of American Folklore, II 2 (445), 254-267. http://doi.org// 0.2307/54/36I sayfasından erişilmiştir.

Şahin, H. (20/5). Günümüz Sanatı ve Pastiş. Süleyman Demirel Üniversitesi Arte-Güzel Sanatlar Fakültesi Sanat Dergisi, 7 (15), I I0-126.

Tanrıbilir, R. N. (20I0). Reklamlarda Melez Kültür Kullanımı ve Değişen Sosyal Değerin Reklamlara Yansıması. Sanatta Yeterlik Tezi, Marmara Üniversitesi Sosyal Bilimler Enstitüsü, Reklamcılık ve Tanıtım Bilim Dalı. İstanbul.

Taşçıŏlu, M. (20/3). Bir görsel iletişim platformu olarak mekân. İstanbul: Yapı Endüstri Merkezi Yayınları.

Türkdoğan, T. (20/4). Sanat Kültür Politika: Modernizm Sonrası Tartışmalar. Ankara: Nobel Yayınları.

Uysal, A. (20I I). Görsel Kültürün ve Sosyo-Kültürel Olgularin Öğrenci Resimlerindeki Imgelere Etkiler. Akademik Bakış Dergisi. (24), I-20. http://www.akademikbakis.org sayfasından erişilmiştir.

Wilson, M. (20I5). Çağdaş Sanat Nasıl Okunur: 2 I. Yüzyıl Sanatını Yaşamak (çev. F. C. Erdoğan). Istanbul: Hayalperest Yayınevi.

Web: Jeny Holzer, http://artaspoliticalvoice.weebly.com/jenny-holzer.html (Erişim tarihi: 15.02.2017). 
Web: Williams, H., (Şubat-2015). “Es Devlin Interview: Meet Britain’s Most

Astonishingly Prolific Designer”, http://www.independent.co.uk/arts-entertainment/ theatre-dance/features/es-devlin-interview-meet-britains-most-astonishingly-prolificdesigner-10029405.html (Erişim tarihi: 25.01.2017).

Yılmaz, M. (20/3). Modernizmden Postmodernizme Sanat. I 27 Sanat Dizisi. Ankara: Ütopya Yayınevi.

Yılmaz, O. (2015). Sanat Akımları Üzerinden Gelişen Disiplinlerarası Sanat. Electronic Turkish Studies, 10 (10), 997-1012.

\section{Görsel Kaynakları}

Görsel I: : https://becksearlescott.files.wordpress.com/2008/I I/techno_buddhal I.jpg Görsel 2: http://artaspoliticalvoice.weebly.com/jenny-holzer.html

Görsel 3: http://www.aicanederland.org/category/uncategorized/page//2/

Görsel 4: https://tr.pinterest.com/pin/46387083035/577028/

Görsel 5: https://almeidatheatre.wordpress.com/category/chimerica/

Görsel 6: Michael Wilson. (2015). Çağdaş Sanat Nasıl Okunur. (çev. F. C. Erdoğan). istanbul: Hayalperest Yayınları, s. 91 